University of Nebraska - Lincoln

DigitalCommons@University of Nebraska - Lincoln

\title{
Mineralization of Nitrogen in Soils Amended with Dairy Manure as Affected by Wetting/Drying Cycles
}

D. B. Watts

USDA-ARS, dwatts@ars.usda.gov

H. A. Torbert

USDA-ARS

S. A. Prior

USDA-ARS

Follow this and additional works at: https://digitalcommons.unl.edu/usdaarsfacpub

Part of the Agricultural Science Commons

Watts, D. B.; Torbert, H. A.; and Prior, S. A., "Mineralization of Nitrogen in Soils Amended with Dairy Manure as Affected by Wetting/Drying Cycles" (2007). Publications from USDA-ARS / UNL Faculty. 597.

https://digitalcommons.unl.edu/usdaarsfacpub/597

This Article is brought to you for free and open access by the U.S. Department of Agriculture: Agricultural Research Service, Lincoln, Nebraska at DigitalCommons@University of Nebraska - Lincoln. It has been accepted for inclusion in Publications from USDA-ARS / UNL Faculty by an authorized administrator of DigitalCommons@University of Nebraska - Lincoln. 


\title{
Mineralization of Nitrogen in Soils Amended with Dairy Manure as Affected by Wetting/Drying Cycles
}

\author{
D. B. Watts, H. A. Torbert, and S. A. Prior \\ USDA-ARS National Soil Dynamics Laboratory, Auburn \\ Alabama, USA
}

\begin{abstract}
Interest in manure management and its effects on nitrogen $(\mathrm{N})$ mineralization has increased in recent years. The focus of this research was to investigate the $\mathrm{N}$-mineralization rates of different soil types in Coastal Plain soils and compare them to a soil from Illinois. Soils with and without dairy composted manure addition were subjected to different wetting/drying cycles [constant moisture at $60 \%$ waterfilled pore space (WFPS) and cycling moisture from 60 to 30\% WFPS] under laboratory conditions at three different temperatures $\left(11^{\circ} \mathrm{C}, 18^{\circ} \mathrm{C}\right.$, and $\left.25^{\circ} \mathrm{C}\right)$. Samples were collected from three different soil types: Catlin (Mollisols), Bama (Ultisols), and Goldsboro (Utilsols). Soil chemical and physical properties were determined to help assess variations in $\mathrm{N}$-mineralization rates. Addition of composted manure greatly impacted the amount of $\mathrm{N}$ mineralized. The amount of manure-derived organic $\mathrm{N}$ mineralized to inorganic forms was mainly attributed to the soil series, with the Catlin (silt loam) producing the most inorganic $\mathrm{N}$ followed by the Goldsboro (loam) and then Bama (sandy loam). This was probably due to soil texture and the native climatic conditions of the soil. No significant differences were observed between the constant and cycling moisture regimens, suggesting that the imposed drying cycle may not have been sufficient to desiccate microbial cells and cause a flush in $\mathrm{N}$ mineralization upon rewetting. Nitrogen mineralization responded greatly to the influence of temperature, with the greatest $\mathrm{N}$ mineralization occurring at $25^{\circ} \mathrm{C}$. The information acquired from this study may aid in predicting the impact of manure application to help increase $\mathrm{N}$-use efficiency when applied under different conditions (e.g., climate season) and soil types.
\end{abstract}

Keywords: Dairy manure, mineralization, nitrogen

Received 2 August 2006, Accepted 13 October 2006

Address correspondence to D. B. Watts, USDA-ARS National Soil Dynamics Laboratory, AuburnAL 36832, USA. E-mail: dwatts@ars.usda.gov 


\section{INTRODUCTION}

In the past two decades, an increased interest in maintaining soil and water quality for a sustainable environment has sparked great concerns about manure management. These concerns have been attributed to increased animal production in confined areas; there has been a decrease in the number of individual farms, and the number of animals on large farms has increased in concentrated areas. This has resulted in large amounts of manure being generated that have to be disposed of as waste. The most feasible method of disposal is land application, but improper land-application practices can result in nutrient contamination of groundwater and surface water, which increases human health and environmental risks. Therefore, it is imperative that the effects of manure application to soil under different abiotic conditions are understood to effectively utilize nutrients without causing adverse effects to the environment.

Nitrogen $(\mathrm{N})$ mineralization can be useful in quantifying the impact management practices and organic amendments have on soil functions and environmental quality. Understanding $\mathrm{N}$-mineralization rates under different abiotic conditions could be important in managing $\mathrm{N}$ more efficiently.

Changes in $\mathrm{N}$ mineralization are directly related to microbial activity and biomass inputs, which are affected by abiotic factors. Nitrogen-mineralization processes are influenced by environmental factors, including temperature and soil moisture (Katterer et al. 1998), soil wetting and drying cycles (Kruse, Kissel, and Cabrera 2004), soil texture (Torbert and Wood 1992), and soil characteristics (Schjonning et al. 1999; Gordillo and Cabrera 1997).

Nitrogen mineralization has been shown to accelerate with increasing soil temperature under conditions found in agricultural systems (Cassman and Munns 1980; Eghball 2000). It has been reported that decomposition is 3.7 times faster at $25^{\circ} \mathrm{C}$ than at $15^{\circ} \mathrm{C}$ and 13 times faster at $15^{\circ} \mathrm{C}$ than at $5^{\circ} \mathrm{C}$ (Vigil and Kissel 1995). The effect of temperature on the rate of $\mathrm{N}$ mineralization can also change with latitude. Campbell et al. (1984) reported that soils in the northern region of the USA were affected more by incubation temperatures than Southern soils. Campbell, Jame, and Winkleman (1984) concluded that this was probably due to the decomposition rate, as a function of temperature, which is related to the amount of readily decomposable organic matter in the soil. Soils in northern climates, where the summer is shorter, have less decomposition occurring in a given year compared to soils in southern climates, which experience long summers.

Mineralization is also greatest when soil moisture is near field capacity and declines with soil drying (Cassman and Munns 1980). Linn and Doran (1984) showed that in most soils microbial activity is optimum when soil water-filled pore space (WFPS) is near $60 \%$, resulting in maximum organic matter decomposition. Anaerobic conditions tend to occur at a WFPS greater than $60 \%$, thereby slowing the decomposition process. Knoepp and Swank (2002) found that there was a significant interaction between soil 
moisture content and soil temperature in $\mathrm{N}$ mineralization. Soil temperature and moisture probably have the greatest influence on nitrification because of their importance in soil aeration.

Franzluebbers et al. (1994) found that $\mathrm{N}$ mineralization can also be related to the amount of soil organic matter (SOM) present in the soil. Agronomic practices that build up SOM by adding crop residues back to the soil greatly impact the fertility of the soil, thereby, increasing the potential for $\mathrm{N}$ mineralization (Wood and Edwards 1992; Torbert, Prior, and Reeves 1999).

Soil texture also affects the rate of $\mathrm{N}$ mineralization in soil. Soil texture that is more conducive to the retention of soil organic carbon (C) and $\mathrm{N}$ is associated with increased soil aggregation (Beare, Hendrix, and Coleman 1994). In soils with high amounts of aggregates, the clay-sized particles are bound around organic material, thereby protecting organic matter from decay (Beare, Hendrix, and Coleman 1994; Jastow 1996). When soil aggregates are destroyed, the organic matter is exposed to microbial attack.

Surface soils, in most ecosystems, experience periods of drying followed by relatively rapid rewetting cycles. It has been shown that mineralization rates of $\mathrm{N}$ are generally increased for a few days following rewetting of a dry soil (Birch 1958; Bloem et al. 1992; Cui and Caldwell 1997; Franzluebbers et al. 2000). Soil undergoes complex physical, chemical, and biological changes under the impact of drying and rewetting, including changes to soil structure (aggregation), SOM, and microflora (Soulides and Allison 1961; Sorensen 1974; Utomo and Dexter 1982).

Wetting and drying cycles have an influence on microbial activity, thereby affecting decomposition of SOM (Soulides and Allison 1961; Bloem et al. 1992; Magid et al. 1999). Drying followed by rapid rewetting cycles generally causes an increase in organic substrate available for microbial attack (Soulides and Allison 1961; Sorensen 1974). These substrates are partially derived from the death of a portion of the soil organisms upon drying (Lund and Goksoyr 1980; Bottner 1985) by causing microbes to undergo osmotic shock, which can induce microbial cell lysis (Bottner 1985; Van Gestel, Ladd, and Amato 1992) or lead to the release of intracellular solutes (Halverson, Jones, and Firestone 2000). The labile substrates that become available (i.e., $\mathrm{C}$ and $\mathrm{N}$ compounds in the form of organic material) are rapidly mineralized by the remaining soil microbes, which causes a pulse in mineralization of $\mathrm{N}$ and $\mathrm{C}$ (Birch 1959; Keift, Soroker, and Firestone 1987). Wetting and drying cycles have also been shown to cause soil aggregates to break apart, exposing physically protected organic matter to further degradation (Adu and Oades 1978; Lundquist, Jackson, and Scow 1999). The organic matter that was previously unavailable can be rapidly mineralized by the microbial community (Appel 1998).

A better understanding of soil under different textural, moisture, and temperature conditions from different climatic regions is needed to develop management practices that optimize $\mathrm{N}$ derived from manure. This could aid in a better quantification of $\mathrm{N}$-use efficiency, because it is presently 
estimated that efficiency is about 30 to $50 \%$ in most agricultural soils, subjecting the soil to excess leaching or runoff (Delgado 2002). Therefore, information is needed on the relative rate of $\mathrm{N}$ being mineralized in soils amended with manure as affected by different climatic conditions. The objective of this study was to determine the impact of manure application on $\mathrm{N}$ mineralization in soils subjected to different temperatures and wetting and drying cycles under laboratory incubation conditions.

\section{MATERIALS AND METHODS}

Soil samples were collected from an ongoing precision agriculture experiment established in 2000 at Auburn University's E.V. Smith Experiment Station located in Macon County, Alabama, and compared to soil under long-term pasture management located in Champaign County, Illinois. Bulk samples $(0-15 \mathrm{~cm})$ were collected from field plots and transported back to the laboratory for analysis.

\section{Soil Description}

Average annual precipitation and temperature in Macon County is $1422 \mathrm{~mm}$ and $17^{\circ} \mathrm{C}$, respectively. Two soil series evaluated from Macon County were Bama and Goldsboro. The Bama series consists of very deep, well-drained soils formed in loamy sediments. Slopes range from 0 to 5\%. These soils are fine-loamy, siliceous, subactive, thermic Typic Paleudults. The Goldsboro series consists of very deep, moderately well-drained soils formed in loamy sediments. Slopes range from 0 to $2 \%$. These soils are fine-loamy, siliceous, subactive, thermic Aquic Paleudults. The farming practice was conventional tillage, which receives inorganic fertilizer in a continuous cotton/corn rotation. The average annual precipitation and temperature in Champaign County are $938 \mathrm{~mm}$ and $11^{\circ} \mathrm{C}$, respectively. The Catlin soil series consists of moderately well-drained, moderately permeable soil on till plains and moraines. These soils formed in loess and in the underlying loam glacial till. Slopes range from 2 to $7 \%$. These soils are fine-silty, mixed, mesic Typic Arguidolls. Farming practice for this soil consisted of pasture management.

\section{Laboratory Analysis}

Air-dried samples were ground to pass thorough a 2-mm sieve and subjected to chemical and physical analysis. Total $\mathrm{C}$ and $\mathrm{N}$ were determined by the DUMAS dry-combustion method using a CN LECO 2000 analyzer (LECO, St. Joseph, MI). Soil characteristics [pH, electrical conductivity (EC), cation 
Table 1. Soil properties

\begin{tabular}{lccc}
\hline Soil series & Bama & Goldsboro & Catlin \\
\hline $\mathrm{pH}$ & 6.7 & 6.5 & 7.2 \\
$\mathrm{EC}\left(\mathrm{mmhos} \mathrm{cm}^{-1}\right)$ & 0.1 & 0.1 & 0.1 \\
$\mathrm{BD}\left(\mathrm{g} \mathrm{cm}^{-3}\right)$ & 1.46 & 1.58 & 1.2 \\
$\mathrm{CEC}\left(\mathrm{cmol} \mathrm{kg}^{-1}\right)$ & 5.8 & 6.3 & 26.77 \\
Total C $\left(\mathrm{g} \mathrm{kg}^{-1}\right)$ & 7.53 & 7.08 & 40.66 \\
Total $\mathrm{N}\left(\mathrm{g} \mathrm{kg}^{-1}\right)$ & 0.72 & 0.78 & 3.14 \\
Sand $(\%)$ & 66.25 & 33.75 & 18.75 \\
Silt $(\%)$ & 21.25 & 17.50 & 15.00 \\
Clay $(\%)$ & 12.50 & 17.50 & 15.00 \\
\hline
\end{tabular}

exchange capacity (CEC), soil extractable calcium $(\mathrm{Ca})$, magnesium $(\mathrm{Mg})$, potassium $(\mathrm{K})$, phosphorus $(\mathrm{P})$, iron $(\mathrm{Fe})$, manganese $(\mathrm{Mn})$, zinc $(\mathrm{Zn})$, copper $(\mathrm{Cu})$, boron $(\mathrm{B})$, and sodium $(\mathrm{Na})$ as described by Hue and Evans (1986) and particle size] were measured by the Auburn University Soil Testing Laboratory. Composted dairy manure was obtained from compost piles located on the Auburn University dairy farm. Total $\mathrm{N}$ was measured using the DUMAS dry-combustion method. Soil properties are presented in Table 1.

\section{Incubation Study}

An aerobic incubation experiment was performed similar to the procedure described by Honeycutt et al. (2005). Treatments were replicated in triplicates with $250 \mathrm{~g}$ of soil (oven-dried weight basis) amended with the appropriate amount of composted dairy manure to give $350 \mathrm{~kg}$ organic $\mathrm{N} \mathrm{kg}^{-1}$ soil. Samples were thoroughly mixed and placed into 2-L Mason ${ }^{\circledR}$ jars. Deionized water was added to bring the soil moisture to approximately $60 \%$ WFPS. The controls were treated with deionized water only. Samples were incubated at three different temperatures $\left(11^{\circ} \mathrm{C}, 18^{\circ} \mathrm{C}\right.$, and $\left.25^{\circ} \mathrm{C}\right)$ and exposed to two wetting/drying regimes. Half were maintained at constant moisture (60\% WFPS), and the other half were cycled from $60 \%$ to $30 \%$ WFPS. Samples were aerated daily $(2 \mathrm{~h})$, at which time moisture content was adjusted gravimetrically as required. Cycled soils were allowed to reach $30 \%$ WFPS to complete a drying cycle. After undergoing a drying cycle, soils were rewetted by adding the appropriate amount of water to bring the soil back to $60 \%$ WFPS. On the day that cycled soils were rewetted to $60 \%$ WFPS, a subsample was taken from the cycled soil and its corresponding soil at constant moisture. Concentration of ammonium $\left(\mathrm{NH}_{4}\right)$ and nitrite $\left(\mathrm{NO}_{2}\right)+$ nitrate $\left(\mathrm{NO}_{3}\right)$ were determined by extraction using $2 \mathrm{M}$ 
$\mathrm{KCl}$ as described by Keeney and Nelson (1982) and measured colorimetrically using a Bran-Luebbe autoanalyzer (Bran-Luebbe, Norderstedt, Germany).

The experiment was analyzed as a completely randomized factorial design with three soil types amended with and without manure and three incubation temperatures. Statistical analyses were performed using the GLM procedure of SAS (SAS Institute 1985), and means were separated using least significant difference (LSD) at an a priori 0.10 probability level.

\section{RESULTS AND DISCUSSION}

Most of the $\mathrm{N}$ assimilated by plants is derived from inorganic $\mathrm{N}$ pools $\left(\mathrm{NH}_{4}\right.$ and $\mathrm{NO}_{3}$ ) generated through the processes of $\mathrm{N}$ mineralization and nitrification. In this study, net $\mathrm{N}$ mineralization rates were determined from the change in the soil inorganic- $\mathrm{N}$ pool size over time where $\mathrm{N}$ mineralization at day 0 was subtracted from each cycle.

The addition of dairy composted manure to the incubated soil significantly increased the amount of inorganic $\mathrm{N}$ produced at the 11,18 , and $25^{\circ} \mathrm{C}$ temperature regimens combined across both the constant and cycling moisture regimens (Figure 1). The amount of ammonium produced was not significantly higher in the soil containing manure compared to that of unamended soils. This result differs from that reported by Honeycutt, Griffin, and He (2005), who used dairy manure in their study, and is probably because dairy compost was used in this study and the $\mathrm{NH}_{4}$ had already undergone nitrification $\left(\mathrm{NH}_{4}\right.$ conversion to $\mathrm{NO}_{3}$ ) or had been volatilized.

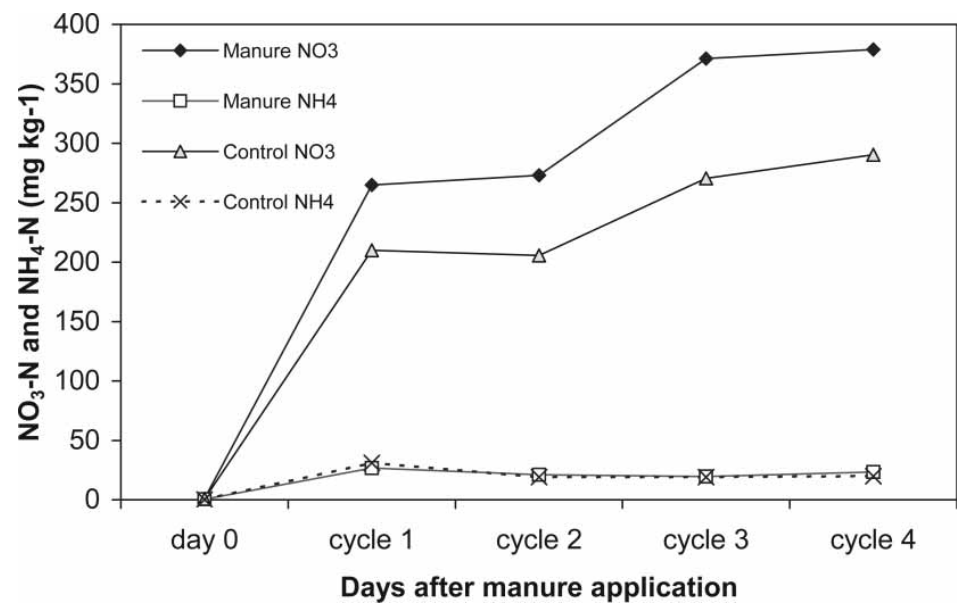

Figure 1. Concentration of nitrate and ammonium following manure application for the Goldsboro soil amended with and without manure combined across three incubation temperatures and the wetting and drying cycles. 
Table 2. Analysis of variance for the effects of soil type, moisture regimen, and temperature

\begin{tabular}{lccccc}
\hline Parameter & Day 0 & Cycle 1 & Cycle 2 & Cycle 3 & Cycle 4 \\
\hline Soil (S) & $<.0001$ & $<.0001$ & $<.0001$ & $<.0001$ & $<.0001$ \\
Moisture (M) & 0.227 & 0.0775 & 0.5465 & 0.275 & 0.8594 \\
Temperature (T) & 0.055 & 0.0003 & 0.0001 & $<.0001$ & $<.0001$ \\
$\mathrm{~S} \times \mathrm{M}$ & 0.2851 & 0.2225 & 0.7612 & 0.1104 & 0.5512 \\
$\mathrm{~S} \times \mathrm{T}$ & 0.2511 & 0.3737 & 0.0003 & 0.0049 & 0.0005 \\
$\mathrm{M} \times \mathrm{T}$ & 0.2006 & 0.0125 & 0.479 & 0.0233 & 0.0894 \\
$\mathrm{~S} \times \mathrm{M} \times \mathrm{T}$ & 0.3418 & 0.3316 & 0.0433 & 0.1258 & 0.0311 \\
\hline
\end{tabular}

Note. Analysis of variance P > F LSD (0.10).

In the succeeding text, the amount of inorganic $\mathrm{N}$ is expressed as the sum of $\mathrm{NH}_{4}$ and $\mathrm{NO}_{3}$. Also, the amount of inorganic $\mathrm{N}$ mineralized was corrected by subtracting soil amended with composted dairy manure from those unamended soils. It is assumed that ammonia volatilization was negligible because most of the $\mathrm{N}$ would be in a stable form $\left(\mathrm{NO}_{3}\right)$ and the compost was incorporated into the soil (Schilke-Gartley and Sims 1993; Hengnirun et al. 1999). Denitrification was also assumed to be negligible because the WFPS was not greater than 60\% (Linn and Doran 1984).

\section{Nitrogen Mineralization as Affected by Soil Type}

Significant differences were observed resulting from soil types (Table 2). The Catlin soil was significantly higher than the Goldsboro and Bama soils for day 0 and all of the sampling periods (Table 3). There were no significant differences observed between the Goldsboro and Bama soils for all of the sampling periods. These soils were collected from the southeastern region of the United States from soils under precision agriculture management. These results showed that land-use planning for agronomic and environmental sustainability may not be useful in manure management of soils that are historically nutrient poor.

Table 3. Mean inogranic $\mathrm{N}$ concentration as affected by soil type over time in $\mathrm{mg} \mathrm{kg}^{-1}$

\begin{tabular}{lccccr}
\hline Soil & Day 0 & Cycle 1 & Cycle 2 & Cycle 3 & Cycle 4 \\
\hline Catlin & $3.497 \mathrm{~b}$ & $80.20 \mathrm{a}$ & $87.66 \mathrm{a}$ & $95.62 \mathrm{a}$ & $102.16 \mathrm{a}$ \\
Goldsboro & $1.147 \mathrm{c}$ & $28.00 \mathrm{~b}$ & $28.27 \mathrm{~b}$ & $37.93 \mathrm{~b}$ & $39.09 \mathrm{~b}$ \\
Bama & $1.244 \mathrm{c}$ & $26.93 \mathrm{~b}$ & $23.17 \mathrm{~b}$ & $30.55 \mathrm{~b}$ & $34.78 \mathrm{~b}$ \\
\hline
\end{tabular}

Note. Means within column followed by the same letter are not significantly different at the 0.10 level using LSD values. 
By evaluating the soil characteristics (Table 1), it can be shown that the Catlin soil greatly varies from the other two soils. Catlin soil has a higher CEC, total C, and total $\mathrm{N}$. The total amount of inorganic $\mathrm{N}$ mineralized in the Catlin soil (Table 3) was 175 and $215 \%$ higher than the Goldsboro and Bama soil, respectively. Even though the Goldsboro soil has higher clay content and is considered to be a better soil than the Catlin, $\mathrm{N}$ mineralization was probably influenced by CEC, total $\mathrm{N}$ and $\mathrm{C}$, and organic matter, resulting from the climate where the soil originated. Soils under cool wet climates tend to build up organic matter (e.g., Catlin), whereas soil from hot humid climates (Goldsboro and Bama) tend to promote organic matter decomposition, and high rainfall events tend to cause leaching. Because $\mathrm{N}$ mineralization is a process that is mediated by microbial activity, the microbial populations of soil from the northern climatic environments were probably more adapted to relatively low soil temperature, therefore causing a higher mineralization in the Catlin soil at $11^{\circ} \mathrm{C}$. As soil temperature increased, the Catlin soil experienced a faster decomposition, due to the residual organic matter.

Unlike results reported by Honeycutt, Griffin, and He (2005), who performed a similar experiment, we did not observe $\mathrm{N}$ immobilization in the Catlin soil. They reported that soil with higher clay and silt contents showed greater $\mathrm{N}$ immobilization when amended with dairy manure compared to the other soils. Sorensen, Jensen, and Nielsen (1994) utilized sheep feces and also found $\mathrm{N}$ immobilization in soil that had the highest clay content. These soils were all compacted to the same bulk density. In the current study, the soil was compacted to the corresponding bulk density observed in the field where they were collected. Our results were similar to the laboratory incubation study of Linn and Doran (1984), who found slightly less respiration with soil of different compactions across a range of WFPS compared with loose, porous soils. Torbert and Wood (1992) observed from sandy coastal plain soils that respiration (measure by amount of $\mathrm{CO}_{2}$ evolved from soil) decreased $65 \%$ when bulk density was increased from 1.4 to $1.8 \mathrm{Mg} \mathrm{m}^{-3}$ at $60 \%$ WFPS. Thus, their results showed that bulk density could impact microbial activity. This also helps explain the higher $\mathrm{N}$ mineralization rate in the Catlin, which had the lowest bulk density $\left(1.2 \mathrm{Mg} \mathrm{m}^{-3}\right)$.

\section{Nitrogen Mineralization as Affected by Soil Moisture}

Soil incubation samples in this experiment were dried at different rates. Drying times varied depending on soil characteristics and temperature. Incubation jars containing a given soil at a particular temperature were sampled when the cycling moisture content reached 30\% WFPS. In general, the amount of time required between each cycling period (to reach $30 \%$ WFPS) decreased as temperature increased.

There was no significant difference observed between the constant and cycling moisture regimens for all soil types regardless of soil texture (Tables 2 and 4). These results are similar to those of Griffin, Honeycutt, and He (2002) 
Table 4. Mean inorganic $\mathrm{N}$ concentration as affected by soil moisture over time in $\mathrm{mg} \mathrm{kg}^{-1}$

\begin{tabular}{llllll}
\hline Moisture & Day 0 & Cycle 1 & Cycle 2 & Cycle 3 & Cycle 4 \\
\hline Cycling & $2.00 \mathrm{a}$ & $47.09 \mathrm{a}$ & $45.62 \mathrm{a}$ & $56.13 \mathrm{a}$ & $58.89 \mathrm{a}$ \\
Constant & $1.92 \mathrm{a}$ & $42.10 \mathrm{a}$ & $47.14 \mathrm{a}$ & $53.26 \mathrm{a}$ & $58.47 \mathrm{a}$ \\
\hline
\end{tabular}

Note. Means within column followed by the same letter are not significantly different at the 0.10 level using LSD values.

and Honeycutt, Griffin, and He (2005). Unlike the results of other researchers (Birch 1964; Cabera 1993) who found that air drying the soil caused a flush in $\mathrm{N}$ mineralization, our results show that drying the soil to $30 \%$ WFPS was not sufficient to desiccate microbial cells, leading to a flush in $\mathrm{N}$ mineralization upon rewetting the soil (Griffin, Honeycutt, and He 2002). Instead, the soil microbes probably adjusted the intercellular solutes to the given water stress level.

Comparing this study to other studies, the drying cycles were performed at a much slower rate than previous reports. The drying cycles in most of the other studies occurred within 1-3 days, which can have an effect on the survival of soil microorganisms (Mikha, Rice, and Milliken 2005). The drying period in this experiment at times took up to 3 weeks. It has been reported that soil drying occurring at a slow rate allows for microbial metabolic adjustment that could reduce mortality (Chao and Alexander 1984; Hartel and Alexander 1986; Roberson and Firestone 1992). Also, the rate of soil drying conducted in this experiment is probably more comparable to that experienced under normal field conditions.

\section{Nitrogen Mineralization as Affected by Soil Temperature}

The amount of inorganic $\mathrm{N}$ mineralized was significantly affected by temperature (Table 2), with the highest two temperatures mineralizing the most in this experiment (Table 5). Dalias et al. (2002) reported that when soils were

Table 5. Mean inorganic $\mathrm{N}$ concentration as affected by soil temperature over time in $\mathrm{mg} \mathrm{kg}^{-1}$

\begin{tabular}{llllll}
\hline Moisture & Day 0 & Cycle 1 & Cycle 2 & Cycle 3 & Cycle 4 \\
\hline $25^{\circ} \mathrm{C}$ & $2.05 \mathrm{a}$ & $48.47 \mathrm{a}$ & $52.58 \mathrm{a}$ & $61.06 \mathrm{a}$ & $67.73 \mathrm{a}$ \\
$18^{\circ} \mathrm{C}$ & $2.00 \mathrm{a}$ & $48.91 \mathrm{a}$ & $47.59 \mathrm{a}$ & $59.31 \mathrm{a}$ & $60.35 \mathrm{~b}$ \\
$11^{\circ} \mathrm{C}$ & $1.84 \mathrm{ab}$ & $37.75 \mathrm{~b}$ & $38.92 \mathrm{~b}$ & $43.72 \mathrm{~b}$ & $47.95 \mathrm{c}$ \\
\hline
\end{tabular}

Note. Means within column followed by the same letter are not significantly different at the 0.10 level using LSD values. 
Table 6. Interaction between soil type and temperature as a measure of inorganic $\mathrm{N}$ over time in $\mathrm{mg} \mathrm{kg}^{-1}$

\begin{tabular}{lcccccc}
\hline Soil & Temp. & Day 0 & Cycle 1 & Cycle 2 & Cycle 3 & Cycle 4 \\
\hline Catlin & $11^{\circ} \mathrm{C}$ & $3.40 \mathrm{a}$ & $68.44 \mathrm{a}$ & $68.55 \mathrm{a}$ & $77.32 \mathrm{a}$ & $79.01 \mathrm{a}$ \\
& $18^{\circ} \mathrm{C}$ & $3.60 \mathrm{a}$ & $85.49 \mathrm{a}$ & $91.64 \mathrm{a}$ & $99.28 \mathrm{~b}$ & $106.87 \mathrm{~b}$ \\
& $25^{\circ} \mathrm{C}$ & $3.48 \mathrm{a}$ & $86.67 \mathrm{a}$ & $102.79 \mathrm{~b}$ & $110.27 \mathrm{~b}$ & $120.61 \mathrm{~b}$ \\
\multirow{4}{*}{ Goldsboro } & $11^{\circ} \mathrm{C}$ & $1.02 \mathrm{a}$ & $24.32 \mathrm{a}$ & $27.38 \mathrm{a}$ & $30.05 \mathrm{a}$ & $35.82 \mathrm{ab}$ \\
& $18^{\circ} \mathrm{C}$ & $1.04 \mathrm{a}$ & $30.14 \mathrm{a}$ & $29.95 \mathrm{a}$ & $48.60 \mathrm{~b}$ & $43.01 \mathrm{a}$ \\
& $25^{\circ} \mathrm{C}$ & $1.39 \mathrm{a}$ & $29.54 \mathrm{a}$ & $27.46 \mathrm{a}$ & $35.11 \mathrm{ab}$ & $38.41 \mathrm{ab}$ \\
\multirow{2}{*}{ Bama } & $11^{\circ} \mathrm{C}$ & $1.09 \mathrm{a}$ & $20.50 \mathrm{a}$ & $20.83 \mathrm{a}$ & $23.79 \mathrm{a}$ & $29.01 \mathrm{a}$ \\
& $18^{\circ} \mathrm{C}$ & $1.36 \mathrm{a}$ & $31.09 \mathrm{a}$ & $21.18 \mathrm{a}$ & $30.07 \mathrm{a}$ & $31.15 \mathrm{ab}$ \\
& $25^{\circ} \mathrm{C}$ & $1.28 \mathrm{a}$ & $29.20 \mathrm{a}$ & $27.42 \mathrm{a}$ & $37.80 \mathrm{a}$ & $44.17 \mathrm{~b}$ \\
\hline
\end{tabular}

Note. Means within column followed by the same letter are not significantly different at the 0.10 level using LSD values.

incubated at $4,10,16,25$, and $30^{\circ} \mathrm{C}, \mathrm{N}$ mineralization increased with temperature. This suggests that the increase in $\mathrm{N}$ pool was related to temperature, indicating an influence of thermal conditions on the degree of microbial exploitation of organic $\mathrm{N}$ sources.

The soil and temperature interaction was significant (Table 2). The Catlin soil showed the greatest difference between temperature regimens (Table 6). This is similar to the finding of Dalias et al. (2002), who found that the optimum temperature for nitrification showed a good correlation with the geographic origin of the soil. This was also in accordance with Campbell, Jame, and Winkleman (1984), who stated that the decomposition rate (as a function of temperature) was related to the amount of readily decomposable organic matter in the soil. Not all organic material decomposes at the same rate. For example, water-soluble carbohydrates, amino acids, and amino sugars have a short residence time in a soil. With an active microbial population under typical summer field conditions, these components are usually consumed within a week or two. Organic matter that is humified or derived from more resistant materials (lignin associated) has longer residence time under the same field conditions and may last years. In northern climates, where summers are cooler and shorter, less decomposition of organic litter and native soil organic matter will occur in a given year, resulting in a buildup of more easily decomposed material over time. In southern climates, summer is longer and warmer, allowing for more complete decomposition of most of the litter material. Over a long period in southern soils, only the most resistant organic materials are left behind, whereas in northern soils, both easily decomposable and resistant materials can accumulate (Campbell, Jame, and Winkleman 1984). 


\section{CONCLUSIONS}

Nitrogen is one of the basic components of life and has a very important function in soil ecosystems. Understanding the effects of manure management in the soil ecosystem and how it relates to the $\mathrm{N}$ cycle is essential in determining $\mathrm{N}$-use efficiency. From this study, it was concluded that temperature and region of soil origin could impact the rate of $\mathrm{N}$ mineralization of soils amended with composted dairy manure. Contrary to results of other studies, we found that soil subjected to cycling moisture regimens did not have a significant affect on the amount of inorganic $\mathrm{N}$ produced. The soil water-stress level imposed in this study suggests that the range may not have been high enough or the drying cycle rapid enough to cause a change in $\mathrm{N}$ mineralization. This was probably because the soil was not dry enough to desiccate microbial cells, which normally leads to a flush in $\mathrm{N}$ mineralization. There was less inorganic $\mathrm{N}$ mineralized from soils of the southeastern region (Goldsboro and Bama: Alabama soils) compared to that from the Midwestern region (Catlin: Illinois soil). Although the particle-size analysis of the Goldsboro soil indicates that it is a finer textured soil, the Catlin was more fertile because of the climate where the soil originated and therefore had a higher N-mineralization potential. Minimal differences were shown between the soil types from the southeastern region. This indicates that the use of precision management in land-use planning for $\mathrm{N}$ mineralization of different soil types of nutrient poor soils (resulting from humid climates and with high leaching potential) may not be useful. This information can also be useful in determining the timing and impact of manure application in different climates and seasons depending on the soil type. Further studies are needed that encompass more soils from different climatic regions to accurately determine the effects of climatic conditions and wetting and drying cycles on soil $\mathrm{N}$ mineralization.

\section{ACKNOWLEDGMENTS}

The authors acknowledge Barry G. Dorman and Sheryl A. Morey (USDAARS National Soil Dynamics Laboratory) for help in overseeing the laboratory study and analysis of the experiment.

\section{REFERENCES}

Adu, J.K. and Oades, J.M. (1978) Physical factors influencing decomposition of organic materials in soil aggregates. Soil Biology and Biochemistry, 10: 109-115.

Appel, T. (1998) Non-biomass soil organic N: The substrate for $\mathrm{N}$ mineralization flushes following soil drying-rewetting and for organic $\mathrm{N}$ rendered $\mathrm{CaCl}_{2}$-extractable upon soil drying. Soil Biology and Biochemistry, 30: 1445-1456. 
Beare, M.H., Hendrix, P.F., and Coleman, D.C. (1994) Water-stable aggregates and organic matter fractions in conventional and no tillage soils. Soil Science Society of America Journal, 58: 777-786.

Birch, H.F. (1958) The effect of soil drying on humus decomposition and nitrogen availability. Plant and Soil, 10: 9-31.

Birch, H.F. (1959) Further observations on humus decomposition and nitrification. Plant and Soil, 9: 262-286.

Birch, H.F. (1964) Mineralization of plant nitrogen following alternate wet and dry conditions. Plant and Soil, 20: 43-49.

Bloem, J., de Ruiter, P.C., Koopman, G.J., Libbink, G.J., and Brussaard, L. (1992) Microbial numbers and activity in dried and rewetted arable soil under integrated and conventional management. Soil Biology and Biochemistry, 24: 655-665.

Bottner, P. (1985) Response of microbial biomass to alternate moist and dry conditions in a soil incubated with ${ }^{14} \mathrm{C}$ and ${ }^{15} \mathrm{~N}$ labeled plant material. Soil Biology and Biochemistry, 17: 329-337.

Cabera, M.L. (1993) Modeling the flush of nitrogen mineralization caused by drying and rewetting soils. Soil Science Society of America Journal, 57: 63-66.

Chao, W.L. and Alexander, M. (1984) Mineral soils as carriers for rhizobium inoculants. Applied and Environmental Microbiology, 47: 94-97.

Campbell, C.A., Jame, Y.W., and Winkleman, G.E. (1984) Mineralization rate constants and their use for estimating mineralization in some Canadian prairie soils. Canadian Journal of Soil Science, 64: 333-343.

Cassman, K.G. and Munns, D.N. (1980) Nitrogen mineralization as affected by soil moisture, temperature, and depth. Soil Science Society of America Journal, 44: $1233-1237$.

Cui, M. and Caldwell, M.M. (1997) A large ephemeral release of nitrogen upon wetting of dry soil and corresponding root responses in the field. Plant and Soil, 191: 291-299.

Dalias, P., Anderson, J.M., Bottner, P., and Couteaux, M. (2002) Temperature responses of net nitrogen mineralization and nitrification in conifer forest soils incubated under standard laboratory conditions. Soil Biology and Biochemisty, 34: 691-701.

Delgado, J.A. (2002) Quantifying the loss mechanisms of nitrogen. Journal of Soil and Water Conservation, 57: 389-398.

Eghball, B. (2000) Nitrogen mineralization from field-applied beef cattle feedlot manure and compost. Soil Science Society of America Journal, 64: 2024-2030.

Franzluebbers, A.J., Haney, R., Honeycutt, C.W., Schomberg, H., and Hons, F. (2000) Flush of carbon dioxide following rewetting of dried soil relates to active organic pools. Soil Science Society of America Journal, 64: 613-623.

Franzluebbers, K., Weaver, R.W., Juo, A.S.R., and Franzluebbers, A.J. (1994) Carbon and nitrogen mineralization form cowpea plants part decomposing in moist and in repeatedly dried and wetted soil. Soil Biology and Biochemistry, 26: 1379-1387.

Gordillo, R.M. and Cabrera, M.L. (1997) Mineralizable nitrogen in broiler litter, II: Effect of selected soil characteristics. Journal of Environmental Quality, 26: $679-1689$.

Griffin, T.S., Honeycutt, C.W., and He, Z. (2002) Effects of temperature, soil water status, and soil type on swine slurry nitrogen transformations. Biology and Fertility of Soils, 36: 442-446.

Halverson, L.J., Jones, T.M., and Firestone, M.K. (2000) Release of intercellular solutes by four soil bacteria exposed to dilution stress. Soil Science Society of America Journal, 64: 1630-1637. 
Hartel, P.G. and Alexander, M. (1986) Role of extracellular polysaccharide production and clays in desiccation tolerance of cowpea bradyrhizobia. Soil Science Society of America Journal, 50: 1193-1198.

Hengnirun, S., Barrington, S., Prasher, S.O., and Lyew, D. (1999) Development and verification of a model simulating ammonia volatilization from soil and manure. Journal of Environmental Quality, 28: 108-114.

Honeycutt, C.W., Griffin, T.S., and He, Z. (2005) Manure nitrogen availability: Dairy manure in northeast and central U.S. soils. Biological Agriculture and Horticulture, 23: $199-214$.

Honeycutt, C.W., Griffin, T.S., Weinhold, B.J., Eghball, B., Albrecht, S.L., Powell, J.M., Woodbury, B.L., Sistani, K.R., Hubbard, R.K., Torbert, H.A., Eigenberg, R.A., Wright, R.J., and Jawson, M.D. (2005) Protocols form nationally coordinated laboratory and field research on manure nitrogen mineralization. Communications in Soil Science and Plant Analysis, 36: 2807-2822.

Hue, N.V. and Evans, C.E. (1986) Procedures Used for Soil and Plant Analysis by the Auburn University Soil Testing Laboratory; Auburn University: Ala.

Jastow, J.D. (1996) Soil aggregation formation and the accrual of particulate and mineral-associated organic matter. Soil Biology and Biochemistry, 28: 656-676.

Katterer, T., Reichstein, M., Anren, O., and Lomander, A. (1998) Temperature dependence of organic matter decomposition: A critical review using literature data analyzed with different models. Biology and Fertility of Soils, 27: 258-262.

Keeney, D.R. and Nelson, D.W. (1982) Nitrogen: Inorganic forms. In Methods of Soil Analysis, Part 1 2nd edn.;Page, A.L. et al. (ed.); Agronomy Monograph no. 9, ASA and SSSA: Madison, Wisc., 643-698.

Keift, T.L., Soroker, E., and Firestone, M.K. (1987) Microbial biomass response to a rapid increase in water potential when dry soil is wetted. Soil Biology and Biochemistry, 19: 119-126.

Knoepp, J.D. and Swank, W.T. (2002) Using soil temperature and moisture to predict forest soil nitrogen mineralization. Biology and Fertility of Soils, 36: 177-182.

Kruse, J., Kissel, D.E., and Cabrera, M.L. (2004) Effects of drying and rewetting on carbon and nitrogen mineralization in soils and incorporated residues. Nutrient Cycling in Agroecosystems, 69: 247-256.

Linn, D.M. and Doran, J.W. (1984) Effect of water-filled pore space on carbon dioxide and nitrous oxide production in tilled and no tilled soils. Soil Science Society of America Journal, 48: 1267-1272.

Lund, V. and Goksoyr, J. (1980) Effects of water fluctuations on microbial mass and activity in soil. Microbial Ecology, 6: 115-123.

Lundquist, E.J., Jackson, L.E., and Scow, K.M. (1999) Wet dry cycles affect DOC in two California agricultural soils. Soil Biology and Biochemistry, 31: 1031-1038.

Magid, J., Kjaergaard, C., Gorissen, A., and Kuikman, P.J. (1999) Drying and rewetting of a loamy sand soil did not increase the turnover of native organic matter, but retarded the decomposition of added 14-C labeled plant material. Soil Biology and Biochemistry, 31: 595-602.

Mikha, M.M., Rice, C.W., and Milliken, G.A. (2005) Carbon and nitrogen mineralization as affected by drying and wetting cycles. Soil Biology and Biochemistry, 37: 339-347.

Roberson, E.B. and Firestone, M.K. (1992) Relationship between desiccations and exopolysaccharide production in a soil Pseudomonas spp. to drying in soil. Applied and Environmental Microbiology, 58: 1284-1291.

SAS Institute. (1985). SAS User's Guide: Statistics; Statistical Analysis System Institute: Cary, N.C. 
Schilke-Gartley, K.L. and Sims, J.T. (1993) Ammonia volatilization from poultry manure-amended soil. Biology and Fertility of Soils, 16: 5-10.

Schjonning, P., Thomsen, I.K., Moberg, J.P., de Jonge, J., Kristensen, K., and Christensen, B.T. (1999) Turnover of organic matter in differently textured soils, I: Physical characteristics of structurally disturbed and intact soils. Geoderma, 80: 177-198.

Sorensen, L.H. (1974) Rate of decomposition of organic matter in soil as influenced by repeated air drying-rewetting and repeated additions of organic material. Soil Biology and Biochemistry, 6: 31-37.

Sorensen, P., Jensen, E.S., and Nielsen, N.E. (1994) The fate of 15 N-labeled organic nitrogen in sheep manure applied to soils of different texture under field conditions. Plant and Soil, 162: 39-47.

Soulides, D.A. and Allison, F.E. (1961) Effect of drying and freezing soils on carbon dioxide production, available mineral nutrients, aggregation, and bacterial population. Soil Science, 91: 291-298.

Torbert, H.A., Prior, S.A., and Reeves, D.W. (1999) Land management effects on nitrogen and carbon cycling in an Ultisol. Communications in Soil Science and Plant Analysis, 30: 1345-1359.

Torbert, H.A. and Wood, C. (1992) Effects of soil compaction and water-filled pore space on soil microbial activity and $\mathrm{N}$ losses. Communications in Soil Science and Plant Analysis, 23: 1321-1331.

Utomo, W.H. and Dexter, A.R. (1982) Changes in soil aggregate water stability induced by wetting and drying cycles in non-saturated soil. Journal of Soil Science, 33: 141-163.

Van Gestel, M., Ladd, J.N., and Amato, M. (1992) Microbial biomass response to seasonal change and imposed drying regimes at increasing depths of undisturbed topsoil profiles. Soil Biology and Biochemistry, 24: 102-111.

Vigil, M.F. and Kissel, D.E. (1995) Rate of nitrogen mineralized from incorporated crop residues as influenced by temperature. Soil Science Society of America Journal, 59: 1636-1644.

Wood, C.W. and Edwards, J.H. (1992) Agroecosystem management effects on soil carbon and nitrogen. Agriculture Ecosystem and the Environment, 39: 123-138. 